\title{
Company sustainable growth as the result of interaction between finance, energy, environmental and social factors (in case of JSC “Gazprom")
}

\author{
A. N. Steblyanskaya ${ }^{1}$, Zhen Wang ${ }^{2}$, A. R. Denisov ${ }^{3}$, Z. V. Bragina ${ }^{3,4}$ \\ ${ }^{1}$ Harbin Engineering University, \\ Nantong dajie, 145, build. 31, 150001, Harbin, China \\ ${ }^{2}$ China University of Petroleum (Beijing), \\ 18, Fuxue Road, 102249, Beijing, China \\ ${ }^{3}$ Kostroma State University, \\ 17, Dzerzhinskogo ul., 156005, Kostroma, Russian Federation \\ ${ }^{4}$ MIREA - Russian Technological University, \\ 78, Vernandskogo pr., Moscow, 119454, Russian Federation
}

For citation: Steblyanskaya A. N., Zhen Wang, Denisov A. R., Bragina Z. V. (2020). Company sustainable growth as the result of interaction between finance, energy, environmental and social factors (in case of JSC “Gazprom"). St Petersburg University Journal of Economic Studies, vol.36, iss. 1, pp. 134-160. https://doi.org/10.21638/spbu05.2020.107

Financial and sustainable growth policies of companies often contradict each other. In this article we analyze possibilities for overcoming this problem by investigating sustainability of financial growth of the largest Russian natural gas company, Gazprom. Unlike traditional interpretations, we consider company sustainability to result from the interaction and interconnection between the financial, energy, environmental, and social subsystems (F-E-Env-S). We analyze the relationship between subsystem indicators using the Higgins Sustainable Growth Index (SGR) and the Sustainable Growth Index (SGSI). Research shows that Gazprom's sustainable growth system is stable, but to avoid destabilization, we propose ways to prevent the development of barriers to their sustainable growth. The article presents an approach that uses Shannon's negentropy to improve discrimination of models of a sustainable data coverage analysis (DEA) system. DEA efficiency is first calculated for all possible subsets of variables and analyzed using Shannon's entropy theory to calculate the degree of importance of each subset in Gazprom's sustainable growth system. Then we combine obtained performance

(c) Санкт-Петербургский государственный университет, 2020 
values and degree of importance to obtain a common performance indicator (CRS), which can significantly improve the discrimination of sustainable growth models. To visualize the transformation of the stability of the system, it is advisable to use the negentropy index. The following factors influence the SGSI level: production, energy saving, environmental rating, environmental footprint, reduction of air pollutant emissions, reduction of wastewater discharges to surface water bodies, environmental expenditures, personnel costs, social expenses, financial leverage, self-financing ratio, and EBITDA.

Keywords: sustainable growth, Higgins sustainable growth rate, Sustainable Growth System methodology, social-energy-environmental factors affecting on sustainable growth, Data Envelopment Analysis, Shannon's entropy.

\section{Introduction}

For the past 130 years or so, economics treated as a social science in which economies modeled as a flow of income between producers and consumers [Hall, Klitgaard, 2014]. In such a model of economics we can see the lack of the environmental protection questions or questions concerning future of human society. In this case, financial growth analysis reflected the prevailing view and ignored measure financial sustainability any other way except for financial evaluation [Adams, Frost, 2008]. The concept of sustainable growth was originally developed by R.C. Higgins [Higgins, 1977]. The company' sustainable growth rate (further - SGR) is the maximum rate of growth in revenue that can be obtained, given the companies' profitability, asset allocation, and desired dividend payout and financial leverage ratios. Thus, Higgins, Ivashkovskaya, Geniberg and others consider sustainable growth as a financial function of the economic system [Higgins, 1977; Ivashkovskaya, 2014; Geniberg, Ivanova, Polyakova, 2009].

However, H. E. Daly and J. Farley emphasized that economic growth would stop when the stream of crucial resources consumed by human life activities [Daly, Farley, 2004]. Nowadays a new position also formulated in the G20 Green Finance Research Group. The Group noted the importance of assessing the environmental and social factors impact on the financially sustainable growth ${ }^{1}$. The same way, at the end of the 20th century, a group from the Chinese Academy of Sciences, Institute of Politics and Management, headed by Academician Niu Wengyuan, has created the concept of "Lagrange's Sustainability Points" for research of financial sustainable growth under influence of changes in ecological, social and economic environment. This concept is allowed to balance three most essential elements of financial sustainable growth by analogy with the idea of an equilibrium point between giant planets gravitational fields which is borrowed from physics (by analogy this is the point of balance between the three elements of sustainable growth such as economic growth, social progress, responsibility for the environment) [Niu, 2011]. The history of humanity proves beyond question that wilderness, too, plays a crucial task in the economic process as well as in the creation of economic value. It is high time, believe that we should accept this fact and consider its consequences for the economic problem of humankind [Bobulescu, 2015; Meadows, Randers, Meadows, 2005]. Of course, nowadays, the state of the ecological environment is an urgent problem. Anthropogenic impact

${ }^{1}$ European Commission Interim report - Financing a sustainable European economy. 2017: 1-72. Available at: https://ec.europa.eu/info/sites/info/files/170713-sustainable-finance-report_en.pdf (accessed: 14.02.2020); G20 Green Finance Study Group. G20 Green Finance Synthesis Report 2016. Available at: http://www.g20.utoronto.ca/2016/P020160815359441639994.pdf (accessed: 14.02.2020). 
on the atmosphere under the influence of progress has reached the maximum level. The ecological situation in modern Russia also leaves much to be desired. The contradiction between the natural environment possibilities and production development has reached a critical situation. As a result, the problem of finding new conditions for mutually beneficial relations between human, economy and nature arises.

Nowadays, in China it is started to upraised companies' sustainable growth research and testing social, environmental and energy factors on SGR or other financial coefficients [Steblyanskaya, Wang Zhen, 2019]. The same way, importance of the sustainable analysis approved by many researchers, like H.E. Daly, C. J.Cleveland, Ch. Hall, J. Lambert, A. Gupta and others [Husillos, González, Gil, 2011; Cleveland et al., 1984; Gupta, Guha, Krishnaswami, 2013]. It is a few researchers who emphasize their works on the interrelation between energy efficiency and financial or economic indicators like D. Murphy, Ch.Hall, J.Lambert [Hall, Lambert, Balogh, 2014; Lambert et al., 2014; Murphy et al., 2011]. There are few publications concerning EROI impact on sustainable growth or vice versa. By understanding the energy efficiency transversality, company' sustainable growth depends on modernization, ecological and social responsibility strategies based on financial structure opportunities for supporting these sustainable areas [Steblyanskaya, Wang Zhen, 2019]. Moreover, economic sustainable growth is directly related to the so-called unacceptable costs of declining social welfare. They arise as a result of social and environmental casualties, with the need for increased pressures on ecosystems [Daly, Farley, 2004]. As Ch. Hall said, "we need to reintegrate Natural Science with Economics" [Hall, Lambert, Balogh, 2014, p. 141]. It is the end of faith-based economics [Lindenberger, Kümmel, 2011; Van Den Bergh, 2013].

In Russia, unfortunately, existing theoretical researches do not pay enough attention to the instruments that would accurately describe methods for achieving sustainable growth. An exception is the research of A.D. Sheremet, who emphasize the importance of developing complex methods for assessing financial sustainability. Also, Z. Bragina and A. Steblyanskaya published their work concerning Financial Sustainable Growth Theory as a result of interaction with Energy, Environmental and Social Processes concerning oil and gas industry, where authors obtain the results showed that the energy efficiency and social indicators influence financial sustainable growth. The situation in Chinese oil and gas companies is the opposite: the financial sustainable growth is mostly influenced by environmental and energy factors. Thus, the study proves that non-financial indicators have a positive effect on the Russian and Chinese oil and gas companies' financial sustainable growth [Steblyanskaya, Wang Zhen, Bragina, 2019]. The same way, professor V. Bocharnikov have a few works concerning wilderness conservation with analysis human behavior influence on Nature conservation, where he suggested that transboundary between wilderness geography and economic indicators could be useful to research for future generation safety [Bocharnikov, 2018; Bocharnikov, Huettman, 2019]. In the long run, environmental protection has certain promoting effect on economic situation, there is long-term co-integration relationship between environmental protection, other investment and economic growth [Bocharnikov, 2012].

The research devoted to the development of the gas industry financial growth system from the sustainable point of view. Unlike traditional understandings, in our research financial sustainable growth is a result of interaction and interconnection between energy, environmental, financial and social processes. In paper we analyze perspective problems 
concerning 2030 financial sustainable growth strategy for Gazprom. The paper presents an approach using Shannon's negentropy to improve the discrimination of data envelopment analysis (DEA) sustainable system models. The purpose of the research is to study social, environmental, energy and financial indicators which can determine the Gazprom' financial sustainable growth.

The research hypothesis is that ensuring sustainable growth today is closely linked to the depletion of natural resources, the level of pollution and environmental degradation. The first task of the research is to obtain a positive change in SGSI/SGR, using the influence of internal factors (input-set of coefficients (see Appendix), output - SGSI/SGR). The second task is to determine the strength of the relationship between the parameters and the strength of the influence parameter on SGSI/SGR, as well as the appointed period when this effect is most effective. It is necessary to choose the parameters that have the maximum impact on sustainable growth. For this purpose, we make a forecast of how SGSI/SGR will change over time, and also justify the composition of indicators on which sustainable growth depends on. In our case, the more external parameters change under the influence of internal ones, the closer is the connection between them. In our case, Shannon entropy is an indicator that shows at what points the impact on the sustainable growth system the greatest. The closer negentropy indicator is to 1 , the more internal parameters have an impact on SGSI/SGR, it means that at this point the relationship between the parameters is dense, the efficiency from the influence of the parameters on SGSI/SGR is maximum. Information entropy shows the minimum dependence of internal indicators on external ones. Negentropy in the study shows the maximum dependence of internal indicators from the external one. We use the negentropy indicator in order to maximally suppress, the maximum bulge point where we can see the most effectively the impact of the inner parameters on sustainable growth.

The paper is organized as follows. The first chapter provides research methodological scheme, samples and software as well as sustainable growth system theoretical background and DEA and negentropy calculation methodology. The second chapter provides Gazprom sustainable growth as the result of interaction between finance, energy, environmental, and social factors modeling results. Authors also provide conclusion and recommendations and set of Study' indices at the Appendix.

\section{Methodology}

\section{Sample and software}

The leader in terms of gas production in Russia among the companies is PJSC Gazprom (see Table 1). In 2015, the company produced $418 \mathrm{bln} \mathrm{m}^{3}$ of gas, which is $66 \%$ of Russian production and $11 \%$ of world production. Gazprom has the highest inventory coverage since $2014^{2}$.

${ }^{2}$ US Energy Information Administration (2016) International Energy Outlook 2016, International Energy Outlook 2016. URL: https://www.eia.gov/outlooks/aeo/er/ (accessed: 15.02.2020); International Energy Agency (2015) World Energy Outlook 2015. URL: http://www.worldenergyoutlook.org/media/ weowebsite/2008-1994/WEO2006.pdf (accessed: 15.02.2020). 
Table 1. Gazprom reserves and production data

\begin{tabular}{|l|c|c|c|c|c|c|c|c|c|c|c|c|}
\hline \multicolumn{1}{|c|}{ Name/Year } & 2005 & 2006 & 2007 & 2008 & 2009 & 2010 & 2011 & 2012 & 2013 & 2014 & 2015 & 2016 \\
\hline $\begin{array}{l}\text { Naturaland } \\
\text { associated gas, } \\
\text { mln m }^{3}\end{array}$ & 555 & 556 & 549 & 550 & 462 & 509 & 513 & 488 & 488 & 445 & 420 & 420 \\
\hline $\begin{array}{l}\text { Gas condensate, } \\
\text { mln t. }\end{array}$ & 11,50 & 11,37 & 11,27 & 10,93 & 10,07 & 11,29 & 12,07 & 12,85 & 14,66 & 14,49 & 15,34 & 15,85 \\
\hline $\begin{array}{l}\text { Gas reserves } \\
\text { (\% from World } \\
\text { reserves) }\end{array}$ & 16,6 & 16,8 & 16,5 & 18 & 18 & 17,6 & 18,3 & 18,3 & 16,6 & 16,8 & 16,9 & 17,1 \\
\hline $\begin{array}{l}\text { Gas production } \\
\text { (\% from World } \\
\text { production) }\end{array}$ & 18,5 & 18,1 & 17,4 & 16,7 & 14,5 & 14,8 & 14,5 & 13,6 & 13,5 & 12,1 & 11,2 & 11,2 \\
\hline EROI & 78 & 79 & 80 & 83 & 79 & 81 & 77 & 75 & 80 & 71 & 76 & 74 \\
\hline $\begin{array}{l}\text { Energy Savings } \\
\text { (ES), th. st. t. }\end{array}$ & 2464 & 2405 & 2489 & 2798 & 2566 & 2718 & 2803 & 2178 & 2318 & 2477 & 2685 & 2762 \\
\hline
\end{tabular}

Note: GitHub web-site. URL: https://github.com/rufimich/DEA (accessed: 21.02.2020)

B a s ed on: Gazprom web-site. URL: http://www.gazprom.ru (accessed: 14.02.2020); [Nogovitsyn, Sokolov, 2014; Steblyanskaya et al., 2019].

Take into consideration Gazprom energy efficiency data, social data, environmental data and financial data ${ }^{3}$. The study carries out twenty years' period between the years 1996 and 2016. Data classified according to the suggestions concerning level of the influences' factors on SGSI/SGR. We calculated models with the help of Python ${ }^{4}$. Sustainable growth models developed by Kostroma State University, Department of biotechnical, technological and information systems. At Figure 1 we describe logic process of the Research from start to the end with the decision intermediate steps within process. At the scheme we also see the decision criteria concerning result analysis with appointed periods when the influence of the input factors more on SGSI/SGR. As we see from scheme, justification that complex changes can be measured through SGSI/SGR, lead researches to seek input indicators with strong interrelation links with SGSI/SGR.

\section{Sustainable growth system methodology}

In the paper, the sustainable growth system we understand as a complex of financial $(F)$, social $(S)$, environmental (Env) and energy $(E)$ subsystems. All subsystems contribute for the company sustainability [Steblyanskaya, Wang Zhen, Bragina, 2019].

${ }^{3}$ Gazprom (2018) Gazprom' Policy in the Energy Efficiency and Energy Savings area. URL: https:// www.gazprom.com/nature/energy-conservation/ (accessed: 02.03.2020). ESRF (2017) Energy Strategy of the Russian Federation till 2035. URL: https://minenergo.gov.ru/node/1920 / (accessed: 02.03.2020).

${ }^{4}$ University of Michigan Coursera (2018) Applied Social Network Analysis in Python URL: https://www.coursera.org/learn/python-social-network-analysis (accessed: 14.02.2020); Sarker DMOF (2014) Python Network Programming book. URL: https://rutracker.org/forum/viewtopic.php?t=4987720 (accessed: 02.03.2020). 


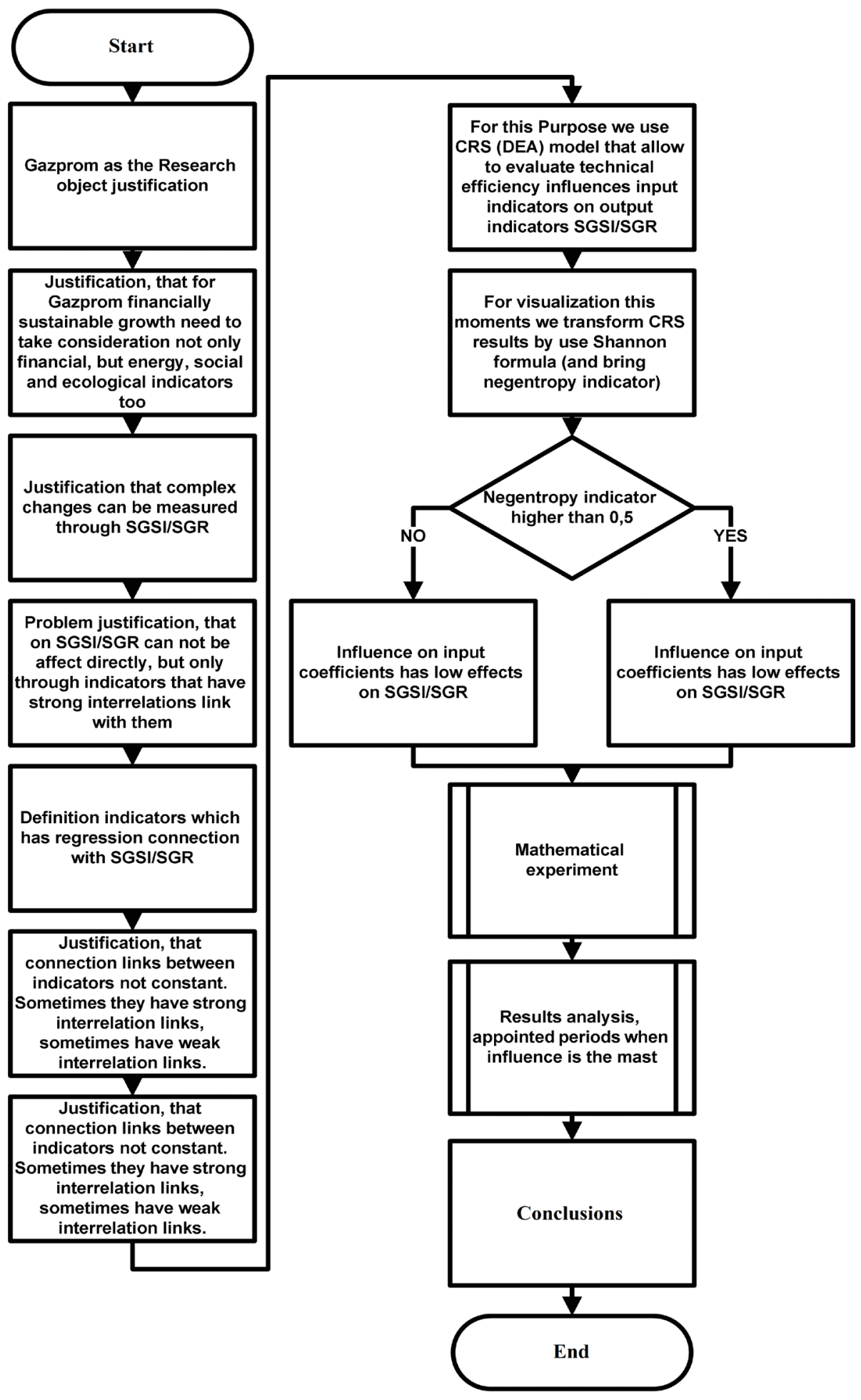

Fig.1. Research scheme 
We have signed out the energy system separately. According to the research of Ch. Hall and D. Murphy, it is the energy indicators that give stability to the system of sustainable growth in General [Murphy et al., 2011; Hall, Balogh, Murphy, 2009]. Nowadays, it is very important to improve energy efficiency, energy sustainability for Russian gas companies [Yan et al., 2019]. Former UN Secretary-General Ban Ki-moon has launched a global initiative to achieve Sustainable Energy for All by 2030. One of the purposes of the effort is doubling the global rate of improvement in energy efficiency ${ }^{5}$. Moreover, the State program on "Energy Saving and Energy Efficiency Improvement until 2020" was adopted by the Russian Ministry of Energy in December 2010 and started the programme in 2011. The program aims to reduce the energy intensity of GDP by $40 \%$ by 2020 compared with 2007; $26.5 \%$ of that reduction should come from structural shifts in the economy and $13.5 \%$ should be achieved through new efficiency measures such as public-private partnerships, loan guarantees for energy efficiency projects, and new standards [Nogovitsyn, Sokolov, 2014]. A Federal Law on Energy Conservation and Increase of Energy Efficiency was adopted in November 2009 to create the legal and economic framework for the promotion of energy efficiency [Gusev, 2016]. Primary purposes of this act are increasing the availability of fuel and energy complex services for the population, increasing the competitiveness of the Russia' fuel and energy complex and Russian energy industry further integration into the World energy system, ensuring activities in the field of environmental safety and the introduction of the best available technologies ${ }^{6}$. Thus, in the Research we also analyze influence Return on Energy Investment (EROI) on Gazprom' sustainable growth. EROI concept originates in ecology and mineralogical resources analysis and represents the ratio of energy expended to energy obtained in the production process [Feng et al., 2018]. A low level of EROI means that a lower coefficient of clean energy provides for the socio-economic system that determines outside the energy analysis. The same way we analyze influence the Energy Savings on Gazprom sustainable growth.

Ecological subsystem $(\boldsymbol{E n} \boldsymbol{v})$. We use next indicators for environmental subsystem: Return on environmental expenses (ROEenv), Environmental Rating $(E R)^{7}$, Environmental Footprint ${ }^{8}$, and Biocapacity ${ }^{9}$, introduced by the World Wildlife Fund (WWF).

Social subsystem $(S)$. We use next indicators for the social subsystem: Return on Labor, Revenue per employee, Return on social investments. Companies' sustainable financial growth also ensuring by social and environmental well-being, employees' high corporate culture [Adams, Frost, 2008].

Financial subsystem $(\boldsymbol{F})$. We use next indicators for the financial subsystem: financial resources demand we predetermine by the "size of the business", which express in the

${ }^{5}$ UN News Centre (2015) "UN adopts new Global Goals, charting sustainable development for people and planet by 2030", United Nations Department of Economic and Social Affairs. URL: https://www.un.org/ en/development/desa/news/sustainable/un-adopts-new-global-goals.html (accessed: 15.02.2020).

${ }^{6}$ Russian Federaton State Programme "Energy Efficiency and Energy Industry development". 30.03.2018 № 371, vol. 12. 2017. URL: https://minenergo.gov.ru/node/1026 (accessed: 15.02.2020).

${ }^{7}$ Gazprom (2018) Gazprom' Policy in the Energy Efficiency and Energy Savings area. URL: https:// www.gazprom.ru/nature/environmental-ratings/ (accessed: 15.02.2020);

${ }^{8}$ Footprint network web-site. URL: https://www.footprintnetwork.org/ (accessed: 15.02.2020); https:// www.footprintcalculator.org/ (accessed: 16.06.2019).

${ }^{9}$ Footprint network web-site. URL: https://www.footprintnetwork.org/resources/glossary/ (accessed: 15.02.2020); https://www.footprintnetwork.org/ (accessed: 15.02.2020); https://www.footprintcalculator. org/ (accessed: 16.06.2019); Gazprom (2018) Gazprom' Policy in the Energy Efficiency and Energy Savings area. https://www.gazprom.ru/nature/environmental-ratings/ (accessed: 15.02.2020). 
cost of company (WACC) and Debt Ratio (DER); financial state we evaluate by use of EBIT (Earnings Before Interest and Taxing), $R G$ (Revenue Growth), $N R G$ (Net profit growth), $N A G$ (Net assets growth) and FL (Financial leverage), CR (Current ratio); financial efficiency we evaluate by use of NWC (Working capital turnover), NWCT (Net Working Capital Turnover ratio), ROS (Return On Sales), ROCE (Return On Capital Employed), ROFA (Return On Fixed Assets), ROE (Return on Equity), ROA (Return On Assets), DOL as operational leverage indicator. Financial growth sustainability we estimate by Higgins' sustainable growth rate [Higgins, 1977]. Full list of Study indicators see in Appendix.

Financial subsystems have widely set of indicators, because of controversial opinions of researcher concerning sustainable growth coefficients. Authors decided the test all variants coefficients that researchers [Higgins, 1977; Ivashkovskaya, 2009; Gupta, Guha, Krishnaswami, 2013] approved as coefficients influence on sustainable growth.

Energy subsystem $(E)$. We use next indicators for energy subsystem: PRP (Production-Reserve Ratio), LEI (Lambert Energy Index) [Lambert et al., 2014] and ES (energy savings) indicator. These energy indicators show the essentiality to protect the natural environment under the sustainable growth framework.

Sustainable growth subsystems are mutually interconnected. Finance is the base of above system framework in real world, as well as energy components provides energy opportunity for system development. Energy subsystem reflects whole system energy transformation. The social component ensures proper resource utilization. Financial subsystem authors associate with all three subsystems and performs a regulatory role in ensuring sustainable growth. The ecological and social subsystems formed under the influence of financial investments in their development. Energy subsystem regulations occur under the influence of the financial and social subsystems [Steblyanskaya, Wang Zhen, Bragina, 2019; Yan et al., 2019].

As shown in Figure 2, sustainable growth in this study is represented by economic, energy and social processes reflected by sets of indicators: financial $(F)$, social $(S)$, environmental (Env) and energy (E). Each block of indices performs a specific function in supporting the company sustainable growth.

The parts of the ecosystem include natural resources and agents of their use: material production, energy, and human environment. Figure 2 shows a schematic diagram of the sustainable growth. We consider natural resources as a source of development of everything: the potential of material production, energy production, and human activity environment. The contradiction "environment - economic development" actualizes not so much the dilemma: either economic development or clean environment, but the need to achieve a common goal: to provide such a potential of material and energy production, that can also the maintain idea of "clean" environment. From this point of view, the economy is a system of resources transformation into a final product, that could catalyze the financial resources for the modernization or innovative renewal of production processes and natural resources' regeneration. To practically implement the strategy of green financial growth, it is necessary to study the interrelationship and mutual influence of the processes that determine the ecological landscape of the economy. 


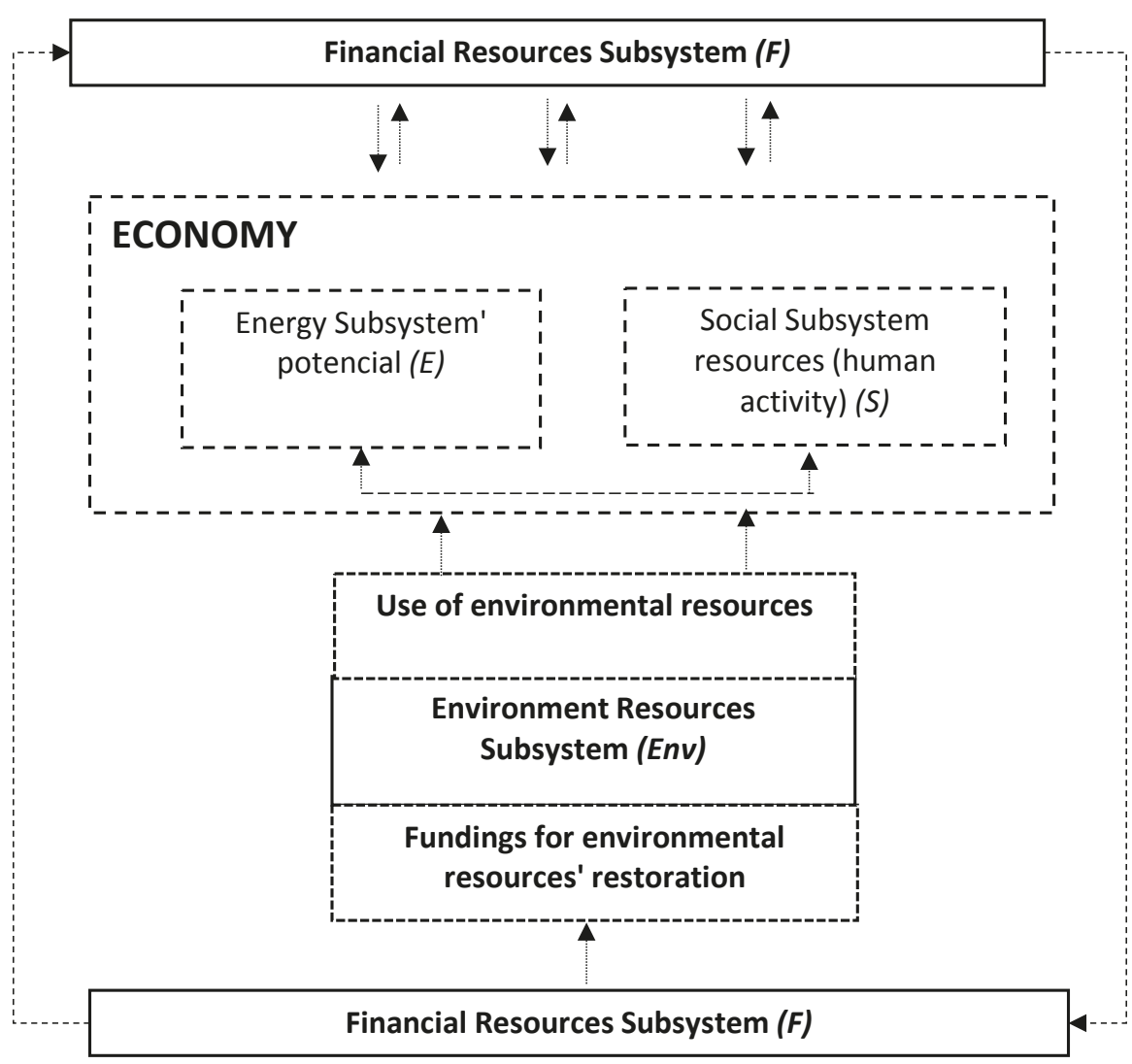

Fig. 2. Financial subsystem interconnections with energy, environmental and social subsystems within the sustainable growth system 1984].

Note: authors' system interpretation, based on research [Lambert et al., 2014; Cleveland et al.,

In the research, we analyze the closeness of relationship between subsystems' indicators that determined by various coefficients. We suggest to use system index that includes all four subsystems indices-financial subsystem index (FI), Energy subsystem index (EI), environmental subsystem index $(E n v I)$, and social subsystem index $(S o c I)$. We calculate an individual index for every period for every subsystem and transform the original data for each subsystem in the range from 0 to 1 by using the following formula:

$$
X_{\text {index }}=\frac{X-X_{\min }}{X_{\max }-X_{\min }} \text {. }
$$

We normalized the subsystem indices from 0 to 1 for guarantees that all variables have the same weight. We took the sustainable growth system index (SGSI) as a geometric average of the four subsystems' indices:

$$
S G S I=\sqrt[4]{F I \cdot E I \cdot S o c I \cdot E n v I} .
$$

If $S G S I<0.2$, then the system is very weakly interconnected. If $0.2<S G S I<0.5-$ the system is weak. If the $S G S I$ is more than 0.5 , but less than 0.7 , then the system is normally 
interconnected. If the SGSI is greater than 0.7, then the system is well connected [Steblyanskaya, Wang Zhen, Bragina, 2019].

\section{Calculation methodology}

The functioning of any sustainable development (or growth) system nevertheless of its characteristics, can be measured and analyzed by effectiveness. We study the system of company' sustainable growth. It is associated with the activities of four subsystems (environmental, energy, social and financial). The result is the creation new sustainable system (SGSI) index. The interaction of these subsystems' indicators we can measure by use of efficiency concept. In this sense, the SGSI/SGR adequately reflecting the results of the material, economic, environmental, energy and financial processes of the company. The system thus acts as a reflector the company's indicators activity in terms of financial, ecology, energy and social responsibility at its "input", and the financial sustainable growth system' results obtained as the "output". In our case system effectiveness is reduced to determining the efficiency of the company's transformation financial, energy, social and environmental resources into results.

We use the concept of permanent changes that companies need to be relevant in the modern world. Thus, in the era of "slowbalization" it is necessary to seek the way of increasing sustainability using nontraditional concepts and develop transversal links between factors (set of indices see in Appendix), influencing on sustainability. For the company's changing in all spheres, specific conditions must arise. A bifurcation point can describe these conditions. A bifurcation point usually appears during a specifically marked parameter increases. Before the bifurcation point, the function solution maintains a monochromic. When the bifurcation point has passed, the function solutions increased, and the number of solutions increases corresponding to the level of bifurcations. Therefore, it is essential to identify and predict such moments with relevant mathematical apparatus.

Authors suggest that the critical parameter of any decision within the company is effectiveness. Where efficiency determined through the research' indicators' target values and costs - available resources for the changes. Thus, we can determine the point in time when changes come on: if predicted effectiveness is high, then this point is convenient for the changes, and if low, then it is not. For the bifurcation points determination, it is enough to estimate the relative efficiency values, which can be implemented using the Constant Returns to Scale (CRS) model of a DEA analysis [Emrouznejad, Cabanda, 2016].

$D E A$ as a relative efficiency evaluation method, has attracted much attention since it was proposed by famous operational research scientists A. Charnes and W. W. Cooper and other scholars in 1987, based on the M. J. Farrel ideas. It has become an important evaluation method in the field of system science and management science. Principle of the method is put forward to make the evaluation by the efficiency of single index based on expanded to multiple input and multiple output. Its function is not only confined to the inefficient evaluation, the management has also greatly enhanced the optimization and prediction. To analyze the shells, we chose the CRS model (we measure line from 0 ). CRS is a private model in the framework of $D E A$. Negentropy in our case - is a mathematical technique to extract the $D E A$ results, to make the results more visible, determining periods where we can observe the financial sustainable growth maximum dependence from the internal factors. 
The authors use the DEA "operational efficiency", which studies process convert inputs to outputs. Depending on the scope of the method DEA the term may have a specific meaning. The $D E A$ method has a number of attractive properties, namely:

- allows to calculate one aggregate for each object in terms of the use of input factors (independent variables) for the production of the desired output products (dependent changes can simultaneously handle many inputs and many outputs, each of which can be measured in different units); allows to take into account external to the system under consideration-environmental variables;

- allows to take into account the importance of the input or output variables;

- focuses on identifying examples of so-called best practices-ticks (best practice), not on any averaged trends like, for example- measures, regression analysis.

The principal methodology of efficiency assessment is Data Envelopment Analysis (DEA), which was suggested by Farrell, Charles, Cooper, Rhodes. These authors developed a CRS model, which subsequently transformed into an input-oriented (resource-minimized) and output-oriented (efficiency-maximized) model.

\section{Input-oriented model}

$$
\begin{gathered}
C R S_{k}-\varepsilon \sum_{r=1}^{q} s_{r}-\varepsilon \sum_{i=1}^{m} s_{i} \rightarrow \min \\
y_{r k}-\sum_{j=1}^{n} \lambda_{j} \cdot y_{r j}+s_{r}=0 \\
C R S_{k} \cdot x_{i k}-\sum_{j=1}^{n} \lambda_{j} \cdot x_{i j}-s_{i}=0 \\
\sum_{j=1}^{n} \lambda_{j}=1
\end{gathered}
$$$$
C R S_{k}, \lambda_{j}, s_{i}, s_{r} \geq 0, \forall r=1 \ldots q,
$$$$
\forall i=1 \ldots m, \forall j=1 \ldots n, \forall k=1 \ldots n .
$$

\section{Output-oriented model}

$$
\begin{gathered}
C R S_{k}+\varepsilon \sum_{r=1}^{q} s_{r}+\varepsilon \sum_{i=1}^{m} s_{i} \rightarrow \max \\
C R S_{k} \cdot y_{r k}-\sum_{j=1}^{n} \lambda_{j} \cdot y_{r j}+s_{r}=0 \\
x_{i k}-\sum_{j=1}^{n} \lambda_{j} \cdot x_{i j}-s_{i}=0 \\
\sum_{j=1}^{n} \lambda_{j}=1
\end{gathered}
$$

$C R S_{k}, \lambda_{j}, s_{i}, s_{r} \geq 0, \forall r=1 \ldots q$,

$\forall i=1 \ldots m, \forall j=1 \ldots n, \forall k=1 \ldots n$.

The graphic presentation of efficiency according to models (4) and (5) is shown in Figure 3.

The efficiency we calculated as follows:

Input-oriented model

$$
C R S=X_{\text {ideal }} / X_{\text {fact }} \text {. }
$$

Output-oriented model

$$
C R S=Y_{\text {ideal }} / Y_{\text {fact }} \text {. }
$$




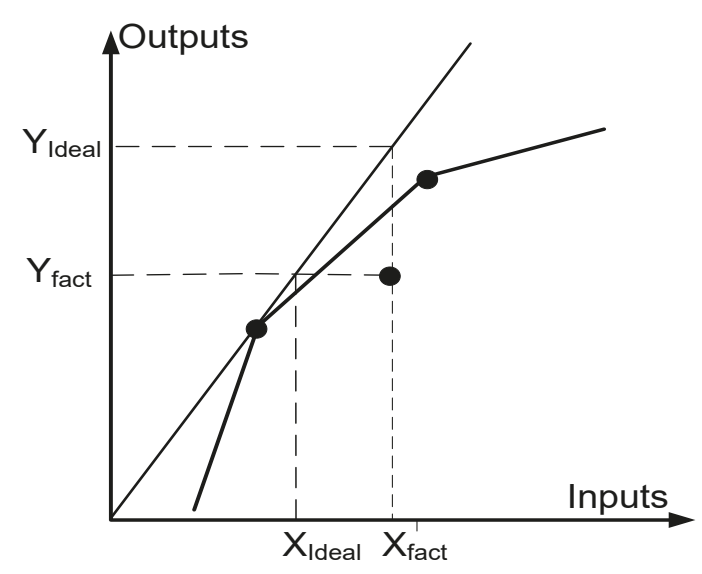

Fig. 3. DEA efficiency graphic presentation Source: [Xie et al., 2014, p. 1577].

The main shortcoming of this approach is linearization of the current input and output parameters' multidimensional space. It introduces an additional error into the optimization task. This error presented in models (6) and (7) as slacks $s$. We need to find the moment when the transformation will take place with the least effort (with minimal resources). Since the goal of the study is to maximize effects, we chose to use the inputoriented model as the basis (see Figure 3).

At Figure 3 there is one point with optimal efficiency (the one through which the line passes). The rest have the worst relative to its efficiency. We see how can we measure the efficiency of the point relative to the leader of the effectiveness, which led on the line $(0,1)$. We project a point on this line and consider efficiency. There is some optimal dependence (direct from 0). It is formed by a weighted set (in DEA, not on the chart) of effective objects. There is some inefficient facility. Inefficiency, in this case, means that it has a lower cost-benefit ratio than the optimal dependency. Visually, this means that it is below the optimal line. The question is how to translate it into optimal. There are two ways: to reduce inputs (resources) without reducing outputs (effects). This is called an input-oriented strategy. The second way to increase output without changing inputs. This is an outputoriented strategy. In the Research we use an input-oriented strategy.

We measure $D E A$ efficiency from 0 till 1 . Technical efficiency is the ratio of the product (outputs) and resources (inputs). That is: $C R S=$ product/resources. The higher level has CRS, the higher level has technical efficiency. The result of the simulation will be a technical efficiency in the range $(0 ; 1]$, which determines the possibility of changes. If the technical efficiency indicator is close to unity, then the company is in a favorable period for changes, but if not, the company in this period is resilient to changes or changes can be ineffective.

The DEA model considers a set of observation points describing the performance of independent production units, the so-called $D M U-$ Decision-Making Units. The results of using the $D E A$ method are very informative from a managerial point of view. This is because along with the obtained estimates of the analyzed objects' effectiveness, the researcher for each inefficient unit extracts information about the composition of the set of active units, concerning which its (inefficient unit) assessment is obtained. The DEA 
method is a benchmarking tool, the use of which not only allows to establish the most effective organizational units but also to distinguish from them the standards for inefficient objects, while determining how far the latter are from the former.

To visualize of the system sustainability transformation, it is advisable to use the negentropy index calculated using the Shannon formula [Chen, Li, 2011; Chakrabarti, Chakrabarty, 2007; Gray, 2009]. Entropy is a measure of the scattering of possible states of a system as it changes (developed) over time. In our study, also, they are optimized for the maximum number of significant factors acting on the system and reflect the effectiveness of the action of a particular system state, the quality of its functioning.

We use the Shannon' formula for visualization of moments that are convenient for transformation:

$$
H=-C R S \cdot \log _{2} C R S-(1-C R S) \cdot \log _{2}(1-C R S) .
$$

Then negentropy will take the form:

$$
n H=1+C R S \cdot \log _{2} C R S+(1-C R S) \cdot \log _{2}(1-C R S) .
$$

In order to avoid false positives $(n H=0)$, it is proposed to use the formula:

$$
n H=\left\{\begin{array}{cc}
1+C R S \cdot \log _{2} C R S+(1-C R S) \cdot \log _{2}(1-C R S) & C R S>0.5 \\
0 & C R S \leq 0.5
\end{array} .\right.
$$

Since the situation when technical efficiency less than 0.1 is doubtful with the CRS model, the CRS values in most cases will show the moments when the efficiency is close to unity. In this case, to eliminate false positives, when CRS is close to zero, it is enough to apply the most straightforward rule, equating the negentropy in this case to zero.

\section{Results}

Authors tested coefficients, which have influence on sustainable growth (SGSI/SGR):

1) environmental factors: ['ER', 'EE', 'ROEenv', 'FOORPRINT', 'BIOCAPACITY', 'Emissions', 'RecultivatedArea', 'Discharge'];

2) financial factors: ['SE', 'PE', 'NP', ' $F L$ ', 'RDS', 'CE', 'SalesRevenue', 'OperatinExpenses', 'EBITDA', 'Assets', 'CurrentAssets', 'Liabilities', 'Debt', 'SFRatio', 'NetCash', 'ROS', 'ROA', 'ROE', 'CurrentRatio',EV_EBITDA'];

3) social factors: ['SE', 'PE'];

4) energy factors: ['Production', 'Reserves', 'EROI', 'ES'].

With the help of Lasso, we have identified important parameters Lasso [Tibshirani, 1996]. We constructed a linear regression and estimated the coefficients by selecting only those parameters for which the allowable interval did not include 0. However, Lasso regression does not allow building confidence intervals. To do this, we calculated the parameters found in the ordinary least square regression (see Tables 2-9).

$S G S I=F$ (Footprint, Emissions, Discharge).

The following factors affect SGSI: Footprint, Emissions of pollutants into the atmosphere, thousand tons, Discharge of wastewater into surface water bodies. 
Table 2. Characteristics of linear regression SGSI = F (Footprint, Emissions, Discharge)

\begin{tabular}{|l|l|l|c|}
\hline \multicolumn{1}{|c|}{ Parameter } & \multicolumn{1}{|c|}{ Value } & \multicolumn{1}{c|}{ Statistic } & Value \\
\hline Dep. Variable & SGSI & Adj. $R^{2}$ & 0.955 \\
\hline Model & OLS & Prob (F-stat.) & $1.03 \mathrm{e}-11$ \\
\hline Method & Least Squares & AIC & -82.44 \\
\hline Date & Sun, 16 Jun 2019 & Prob(Omnibus) & 0.011 \\
\hline Time & $16: 48: 27$ & Skew & -0.964 \\
\hline No. observations & 21 & Kurtosis & 5.102 \\
\hline Df Residuals & 17 & Durbin-Watson & 2.041 \\
\hline Df Model & 3 & Prob (Jarque-Bera) & 0.0284 \\
\hline Covariance type & HC1 & Cond. no. & 75.8 \\
\hline
\end{tabular}

Note: GitHub web-site. URL: https://github.com/rufimich/DEA (accessed: 21.02.2020).

Table 3. Coefficients of linear regression SGSI = F (Footprint, Emissions, Discharge)

\begin{tabular}{|l|c|c|c|c|c|c|}
\hline \multirow{2}{*}{ Variable } & \multirow{2}{*}{ Coef. } & \multirow{2}{*}{ std err } & \multirow{2}{*}{$\mathrm{z}$} & $\mathrm{P}>|\mathrm{z}|$ & \multicolumn{2}{c|}{ Confidence interval } \\
\cline { 5 - 7 } & & & & & $\mathrm{p}=\mathbf{0 . 0 2 5}$ & $\mathrm{p}=\mathbf{0 . 9 7 5}$ \\
\hline Intercept & 0.3714 & 0.283 & 1.313 & 0.189 & -0.183 & 0.926 \\
\hline Footprint & 0.6056 & 0.192 & 3.155 & 0.002 & 0.229 & 0.982 \\
\hline Emissions & -0.9263 & 0.176 & -5.267 & 0.000 & -1.271 & -0.582 \\
\hline Discharge & 0.1764 & 0.053 & 3.353 & 0.001 & 0.073 & 0.280 \\
\hline
\end{tabular}

N o te: GitHub web-site. URL: https://github.com/rufimich/DEA (accessed: 21.02.2020).

We also check the influence environmental factors on SGR.

$$
S G R=F(E E, \text { Footprint, Emissions })
$$

The following factors affect $S G R$ : Company's expenses on environmental protection, a Footprint, Emissions of pollutants into the atmosphere.

Table 4. Characteristics of linear regression $S G R=F$ (EE, Footprint, Emissions)

\begin{tabular}{|l|l|l|c|}
\hline \multicolumn{1}{|c|}{ Parameter } & \multicolumn{1}{c|}{ Value } & \multicolumn{1}{c|}{ Statistic } & Value \\
\hline Dep. Variable & SGR & Adj. $R^{2}$ & 0.559 \\
\hline Model & OLS & Prob (F-stat.) & 0.000972 \\
\hline Method & Least Squares & AI & -90.14 \\
\hline Date & Sun, 16 Jun 2019 & Prob(Omnibus) & 0.024 \\
\hline Time & $16: 48: 44$ & Skew & -0.786 \\
\hline No. observations & 21 & Kurtosis & 4.944 \\
\hline Df Residuals & 17 & Durbin-Watson & 2.195 \\
\hline Df Mode & 3 & Prob(Jarque-Bera) & 0.0649 \\
\hline Covariance type & HC1 & Cond. no. & 72.1 \\
\hline
\end{tabular}

Note: GitHub web-site. URL: https://github.com/rufimich/DEA (accessed: 21.02.2020). 
Table 5. Coefficients of linear regression SGR $=F($ EE, Footprint, Emissions)

\begin{tabular}{|l|c|c|c|c|c|c|}
\hline \multirow{2}{*}{ Variable } & Coef. & std err & \multirow{2}{*}{$\mathrm{z}$} & $\mathrm{P}>|\mathrm{z}|$ & \multicolumn{2}{c|}{ Confidence interval } \\
\cline { 5 - 7 } & & & & & $\mathrm{p}=\mathbf{0 . 0 2 5}$ & $\mathrm{p}=\mathbf{0 . 9 7 5}$ \\
\hline Intercept & -0.4399 & 0.159 & -2.770 & 0.006 & -0.751 & -0.129 \\
\hline EE & -0.1513 & 0.072 & -2.104 & 0.035 & -0.292 & -0.010 \\
\hline Footprint & 0.5169 & 0.106 & 4.887 & 0.000 & 0.310 & 0.724 \\
\hline Emissions & 0.2814 & 0.098 & 2.861 & 0.004 & 0.089 & 0.474 \\
\hline
\end{tabular}

Note: GitHub web-site. URL: https://github.com/rufimich/DEA (accessed: 21.02.2020).

The same way, we build optimal model with social and financial factors influence on Sustainable Growth System Index.

$$
S G S I=F(S E, P E, F L, \text { SFRatio })
$$

Emissions of pollutants into the atmosphere concerning SGSI is with a minus, that means the sustainable system in a whole has positive trend for green growth.

The following factors affect SGSI: social expenses, personal expenses, financial leverage and self-financing ratio.

Table 6. Characteristics of linear regression SGSI = F (SE, PE, FL, SFRatio)

\begin{tabular}{|l|l|l|c|}
\hline Parameter & Value & Statistic & Value \\
\hline Dep. Variable & SGSI & Adj. $R^{2}$ & 0.924 \\
\hline Model & OLS & Prob (F-stat.) & $2.14 \mathrm{e}-08$ \\
\hline Method & Least Squares & AIC & -70.50 \\
\hline Date & Sun, 16 Jun 2019 & Prob(Omnibus) & 0.391 \\
\hline Time & $16: 49: 20$ & Skew & -0.570 \\
\hline No. observations & 21 & Kurtosis & 2.950 \\
\hline Df Residuals & 16 & Durbin-Watson & 1.639 \\
\hline Df Model & 4 & Prob(Jarque-Bera) & 0.566 \\
\hline Covariance type & HC1 & Cond. no. & 27.0 \\
\hline
\end{tabular}

Note: GitHub web-site. URL: https://github.com/rufimich/DEA (accessed: 21.02.2020).

Table 7. Coefficients of linear regression SGSI =F (SE, PE, FL, SFRatio)

\begin{tabular}{|l|c|c|c|c|c|c|}
\hline \multirow{2}{*}{ Variable } & \multirow{2}{*}{ Coef. } & \multirow{2}{*}{ std err } & \multirow{2}{*}{$\mathbf{z}$} & $\mathbf{P}>|\mathbf{z}|$ & \multicolumn{2}{c|}{ Confidence interval } \\
\cline { 5 - 7 } & & & & & $\mathbf{p}=\mathbf{0 . 0 2 5}$ & $\mathbf{p}=\mathbf{0 . 9 7 5}$ \\
\hline Intercept & -0.2122 & 0.059 & -3.571 & 0.000 & -0.329 & -0.096 \\
\hline SE & 0.4173 & 0.124 & 3.355 & 0.001 & 0.174 & 0.661 \\
\hline PE & 0.3276 & 0.126 & 2.608 & 0.009 & 0.081 & 0.574 \\
\hline FL & 0.4179 & 0.084 & 5.003 & 0.000 & 0.254 & 0.582 \\
\hline SFRatio & -0.0734 & 0.036 & -2.034 & 0.042 & -0.144 & -0.003 \\
\hline
\end{tabular}

Note: GitHub web-site. URL: https://github.com/rufimich/DEA (accessed: 21.02.2020). 
The last optimal model checks all sustainable factors using in our Research on Sustainable Growth System Index (SGSI).

Optimal model:

$S G S I=F($ Production, ES, ER, SE, PE, EBITDA).

The following factors affect SGSI: Production, energy savings, environmental rating, social expenses, personal expenses and EBITDA. Model results shows that Energy subsystem has influence on Sustainable Growth System Index.

Table 8. Characteristics of linear regression SGSI = F (Production, ES, ER, SE, PE, EBITDA)

\begin{tabular}{|l|l|l|c|}
\hline \multicolumn{1}{|c|}{ Parameter } & \multicolumn{1}{c|}{ Value } & \multicolumn{1}{c|}{ Statistic } & Value \\
\hline Dep. Variable & SGSI & Adj. $R^{2}$ & 0.963 \\
\hline Model & OLS & Prob (F-stat.) & $2.47 \mathrm{e}-10$ \\
\hline Method & Least Squares & AIC & -84.34 \\
\hline Date & Sun, 16 Jun 2019 & Prob(Omnibus) & 0.422 \\
\hline Time & $16: 51: 06$ & Skew & -0.589 \\
\hline No observations & 21 & Kurtosis & 2.681 \\
\hline Df Residuals & 14 & Durbin-Watson & 2.209 \\
\hline Df Model & 6 & Prob(Jarque-Bera) & 0.521 \\
\hline Covariance type & HC1 & Cond. no. & 49.2 \\
\hline
\end{tabular}

Note: GitHub web-site. URL: https://github.com/rufimich/DEA (accessed: 21.02.2020).

Table 9. Coefficients of linear regression SGSI = F (Production, ES, ER, SE, PE, EBITDA)

\begin{tabular}{|l|c|c|c|c|c|c|}
\hline \multirow{2}{*}{ Variable } & \multirow{2}{*}{ Coef. } & std err & \multirow{2}{*}{$\mathrm{z}$} & $\mathrm{p}>|\mathrm{z}|$ & \multicolumn{2}{c|}{ Confidence interval } \\
\cline { 5 - 7 } & & & & & $\mathbf{p}=\mathbf{0 . 0 2 5}$ & $\mathrm{p}=\mathbf{0 . 9 7 5}$ \\
\hline Intercept & -0.5574 & 0.113 & -4.923 & 0.000 & -0.779 & -0.335 \\
\hline Production & 0.2825 & 0.116 & 2.429 & 0.015 & 0.055 & 0.511 \\
\hline ES & 0.3615 & 0.102 & 3.541 & 0.000 & 0.161 & 0.562 \\
\hline$E R$ & 0.1748 & 0.057 & 3.088 & 0.002 & 0.064 & 0.286 \\
\hline$S E$ & 0.2079 & 0.106 & 1.968 & 0.049 & 0.001 & 0.415 \\
\hline$P E$ & 0.2293 & 0.101 & 2.269 & 0.023 & 0.031 & 0.427 \\
\hline EBITDA & 0.1601 & 0.049 & 3.297 & 0.001 & 0.065 & 0.255 \\
\hline
\end{tabular}

Note: GitHub web-site. URL: https://github.com/rufimich/DEA (accessed: 21.02.2020).

Then, authors evaluate the effectiveness of the selected spaces (see Figure 4).

Authors observe more and more the dependence of SGSI/SGR indicators of the environment. The connection between the parameters is enhanced. Figure 5 shows that SGSI technical efficiency $(C R S)$ has a definite growth trend. At the beginning of the study period (1996), the $C R S$ was below 0.2 , that means that sustainability was difficult to influence through FOOTPRINT + Emissions + Discharge. However, after 2025, a high CRS value is predicted, causing a significant increase in the degree of closeness between the input and output parameters. CRS negentropy index also confirmed this fact. SGR also is quite 


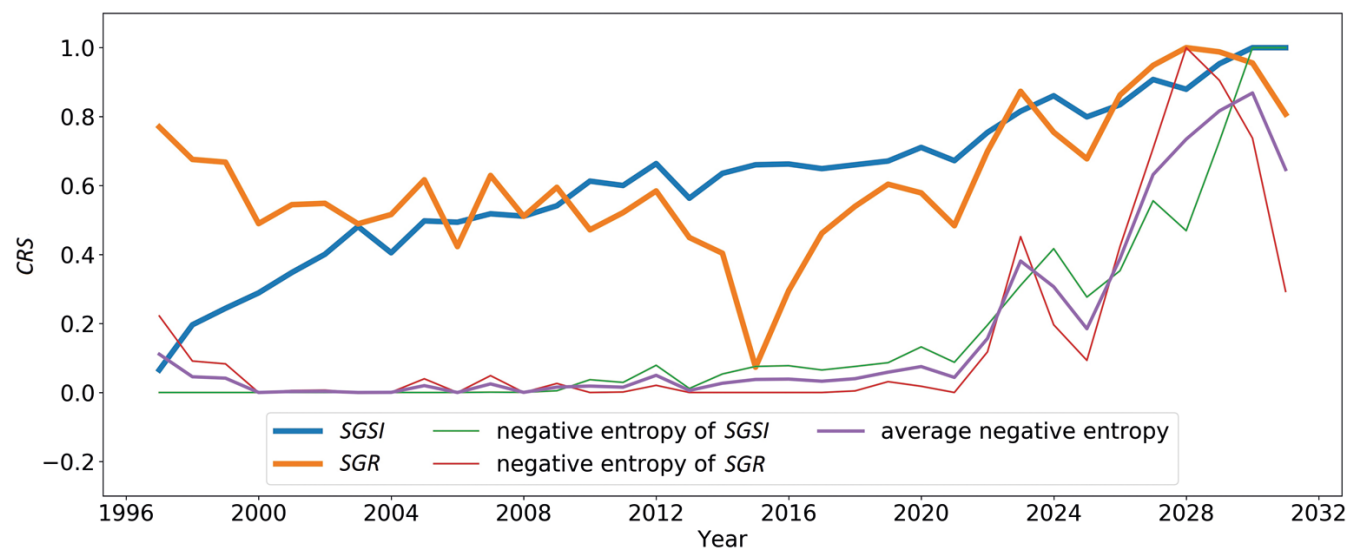

Fig. 4. Technical efficiency (DEA) from footprint, emissions of pollutants into the atmosphere, thousand tons, and discharge of wastewater into surface water bodies, $\mathrm{mln} \mathrm{m}^{3}$

Note: GitHub web-site. URL: https://github.com/rufimich/DEA (accessed: 21.02.2020).

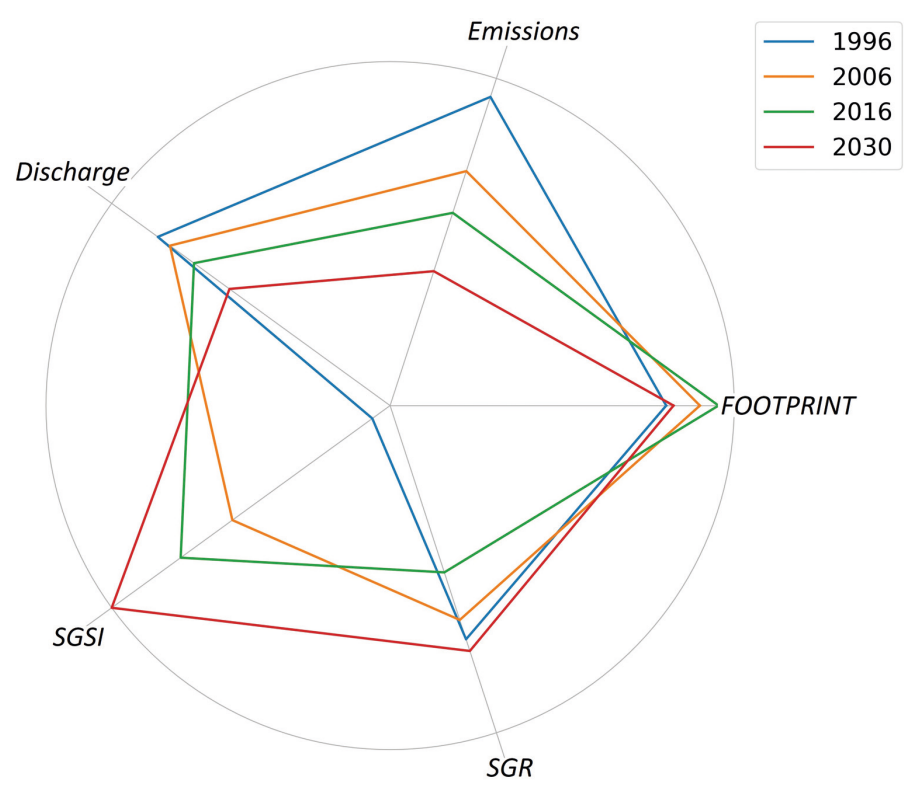

Fig. 5. Values of parameters in 1996, 2006, 2016 and 2030

No te: GitHub web-site. URL: https://github.com/rufimich/DEA (accessed: 21.02.2020).

stable up to 2020 with a maximum growth after 2025. Thus, after 2025, the occurrence of the bifurcation points in terms of SGSI and SGR is predicted through Footprint, emissions of pollutants into the atmosphere, and discharge of wastewater into surface water bodies.

If the indicator's value further from the frame, then changes have a deficient effect on the indicator, that means the system is stable. We solve the problem of how to achieve the maximum effect using the least effort method. Moreover, those points that are at the top of the frame have more effect. It turns out to be a sustainable system with low technical efficiency. If system technical efficiency has a high level, that means that it has a low level 


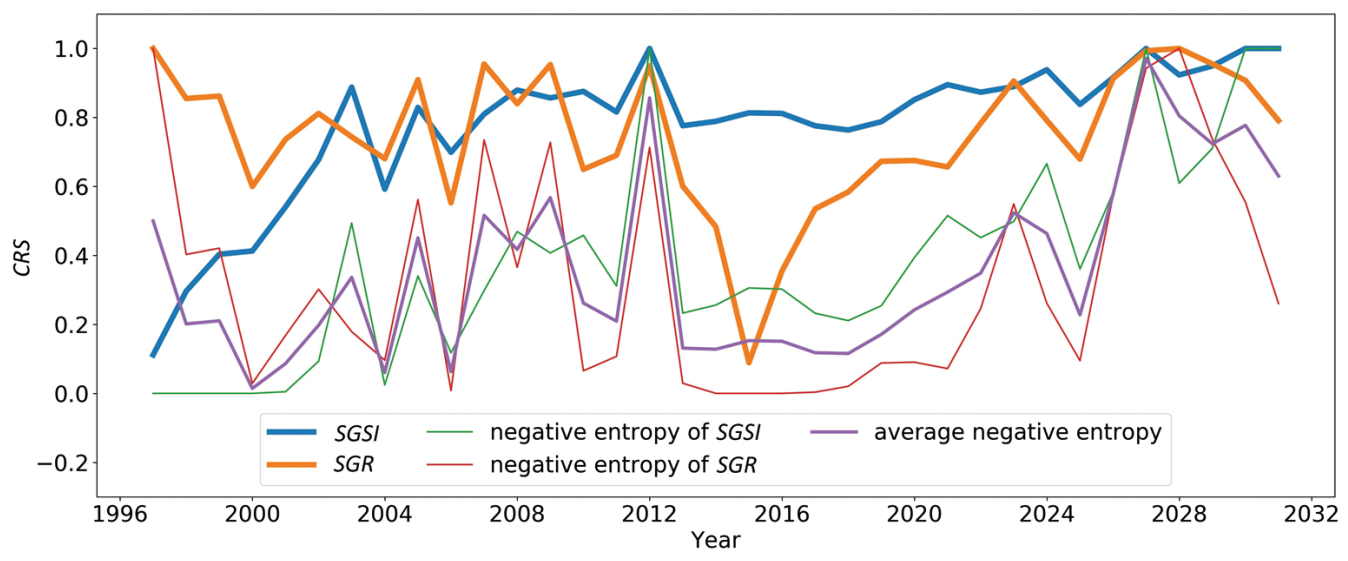

Fig. 6. Technical efficiency (DEA) from footprint, emissions of pollutants into the atmosphere, and environmental expenses

Note: GitHub web-site. URL: https://github.com/rufimich/DEA (accessed: 21.02.2020).

of stability. Negentropy suggests that technical efficiency is closer to 1 (in this case indicator is closer to the frame). Figure 6 shows that emissions of pollutants and the discharge of wastewater into decrease till 2030 that are controversial research results. However, despite the doubts of the forecast evaluation concerning ecological factors, the documents concerning environment protection approved at the State level precisely follow aim to reduce emissions until 2030. SGR is at the average level increasing. SGSI, a footprint is at the high-level point at 2030.

Figure 6 shows that the SGSI technical efficiency (CRS) is at a stable level. At the beginning of the study period (1996), the CRS was below 0.2, that means that sustainability was difficult to influence through Footprint, Emissions of pollutants into the atmosphere, and Environmental Expenses. SGR also is a quite stable level except 2013-2017 because of Gazprom was involved in the first stage of the modernization program. SGSI negentropy is for about 0.4-0.5 level that show us that measure we can to take for pollutants emissions decreasing or environmental expenses increasing justified and have high efficiency. SGR negentropy level less than SGSI. Thus, after 2025, the occurrence of the bifurcation points in terms of SGSI and SGR is predicted through Footprint, Emissions of pollutants into the atmosphere, and Environmental Expenses.

Figures 7, 8 show that emissions of pollutants into the atmosphere, as well as the discharge of wastewater into surface water bodies, decrease till 2030.

$S G R$ is at the average level increasing. SGSI, footprint, environmental expenses are at the high - level point in 2030.

Figure 8 shows that the SGSI technical efficiency (CRS) has a flat, stable line until 2030.

At the beginning of the study period (1996), the CRS was below 0.2. It means that sustainability, expressed by the SGSI index, is relatively difficult to influence social expenses, personal expenses, financial leverage and self-financing ratio. All indicators have a quite stable level except 2013-2017 because Gazprom was involved in first stage of innovation program. Also, after 2020, a high CRS value is predicted, causing a significant increase in the degree of interaction between the input and output parameters. CRS SGSI negentropy 


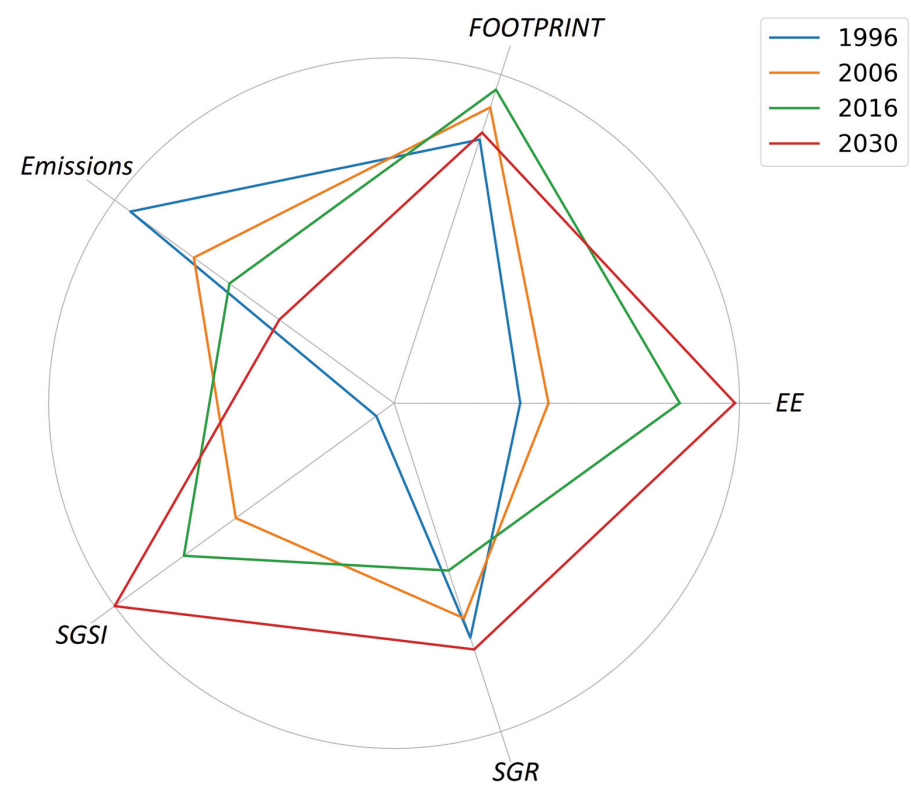

Fig. 7. Values of parameters in 1996, 2006, 2016 and 2030

Note: GitHub web-site. URL: https://github.com/rufimich/DEA (accessed: 21.02.2020).

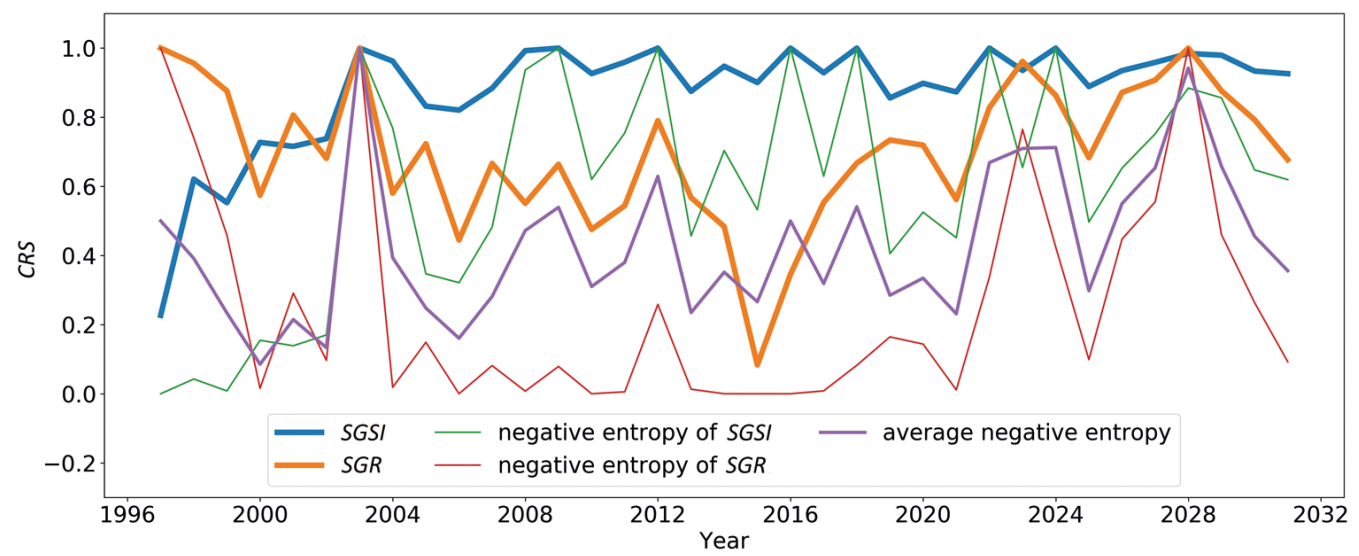

Fig. 8. Technical efficiency (DEA) from social expenses, personal expenses, financial leverage, and self-financing ratio

Note: GitHub web-site. URL: https://github.com/rufimich/DEA (accessed: 21.02.2020).

index has high level of fluctuations between $0.5-1$ points. CRS SGR negentropy has more stable results but at the level 0-0.3 points, social and personal expenses have not influence on SGR. Thus, after 2020, the occurrence of the bifurcation points in terms of SGSI and $S G R$ is predicted when exposed through social expenses, personal expenses, financial leverage, and self-financing ratio.

Figures 9, 10 show that $S G R$ is at the average level increasing. SGSI, personal expenses, social expenses, financial leverage, and self-financing ratio, are at the high - level point at 2030 . 


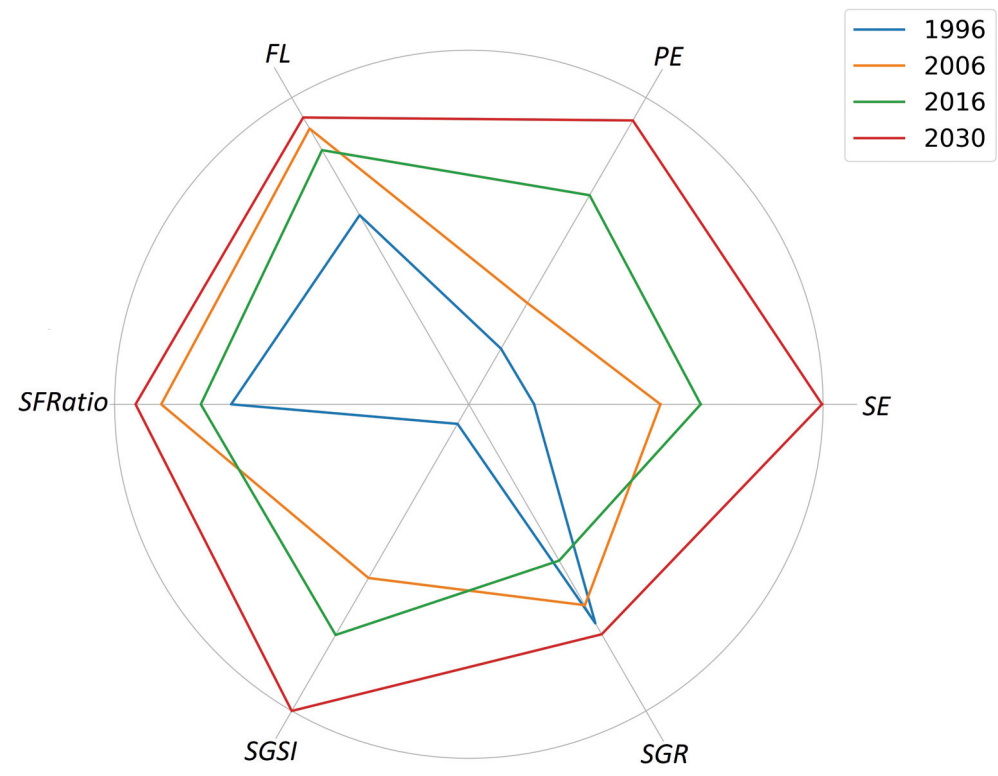

Fig. 9. Values of parameters in 1996, 2006, 2016 and 2030

Note: GitHub web-site. URL: https://github.com/rufimich/DEA (accessed: 21.02.2020).

Figure 10 shows that the SGSI technical efficiency (CRS) SGSI has a definite stable trend.

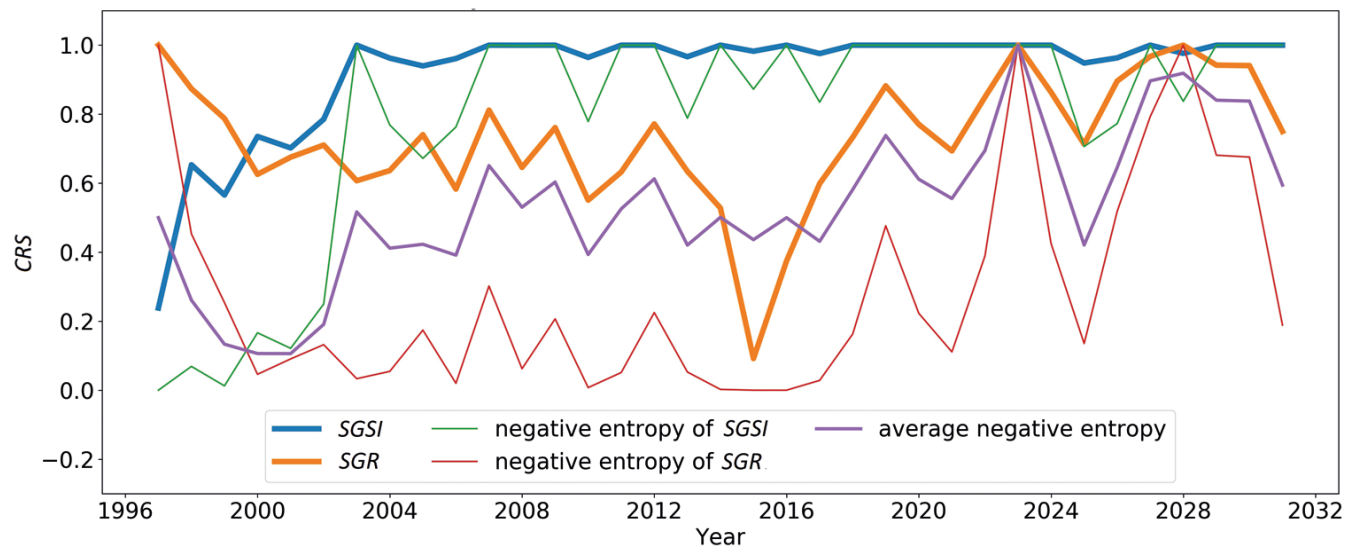

Fig. 10. Technical efficiency (DEA) from production, energy savings, social expenses, personal expenses, EBITDA

Note: GitHub web-site. URL: https://github.com/rufimich/DEA (accessed: 21.02.2020).

Indeed, at Figure 10 we can see that at the beginning of the study period (1996), the $C R S$ was below 0.2 . It means that sustainability, expressed by the SGSI index, is relatively difficult to influence production, energy savings, social expenses, personal expenses, and EBITDA. However, after 2020, a high CRS value is predicted, causing a significant increase in the degree of interaction between the input and output parameters. CRS SGSI negent- 
ropy index confirmed this fact. $S G R$ is up to 2020 increasing quite stable with a sharp drop due to the implementation of the production modernization program. CRS SGR negentropy parameters show that we needn't to pay attention to financial factors too much. At the same time after 2020, the growth of this indicator projected with a maximum after 2025. Thus, after 2025, the occurrence of the bifurcation points in terms of SGSI and SGR is predicted when exposed through production, energy savings, social expenses, personal expenses, and earnings before interests and taxes, depreciation and amortization.

Figure 11 shows that $S G R$ average level is increasing. SGSI, personal expenses, social expenses, production, earnings before interests and taxes, depreciation and amortization and energy savings are at the high point in 2030.

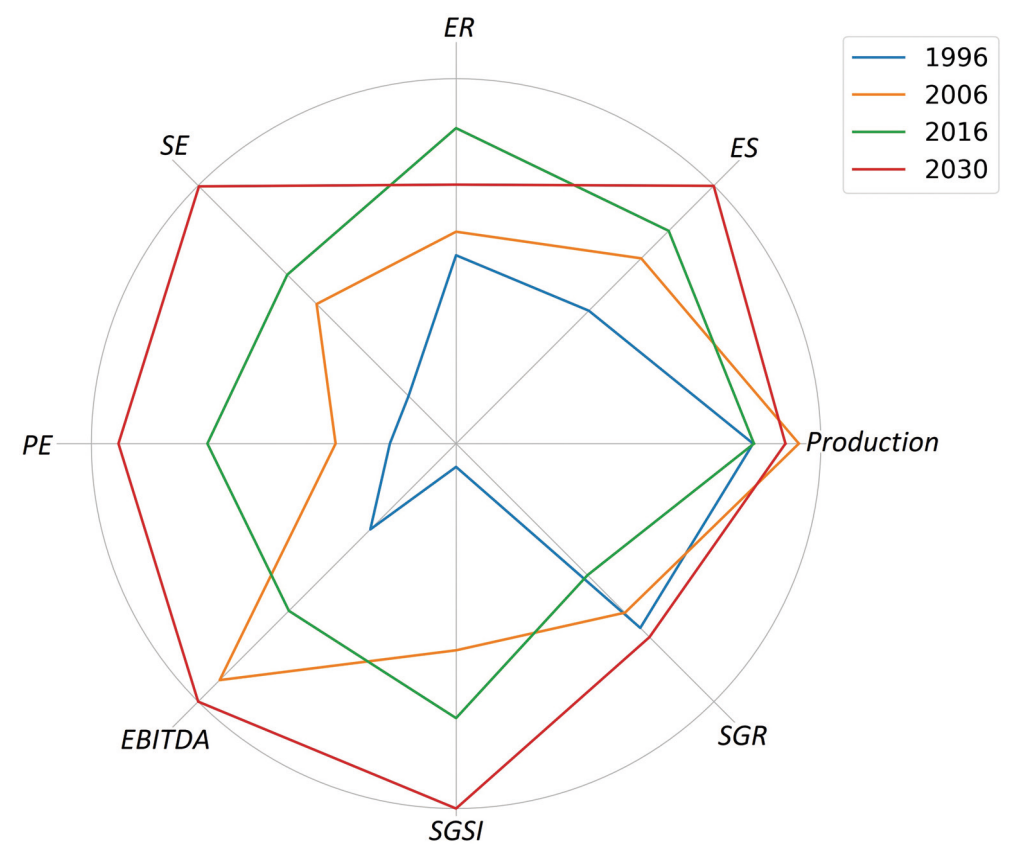

Fig. 11. Values of parameters in 1996, 2006, 2016 and 2030

N o te: GitHub web-site. URL: https://github.com/rufimich/DEA (accessed: 21.02.2020).

However, the environmental rating can be less than the level in 2016.

\section{Conclusion and recommendations}

Companies' sustainable growth is becoming a central debatable element of countries' economic development. Nowadays, the phenomenon of sustainable business growth considered as a managerial function focused on financial, competitive market conditions and for which non-financial factors were not essential.

The article provides a theoretical base for the development of sustainable growth system at the Russian gas companies. For the last ten years, the ambiguous situation in the relation of the Russian gas companies observed. On the one hand, companies' reports show conservative financial policy and stable growth for previous years, on the other hand, the level of financial performance is insufficient that reflects discrepancy of the existing ap- 
proaches to sustainable growth. Besides, in Russia, sustainable growth concept is associated only with financial performance, while the Western and Chinese researchers agree that it is necessary to consider sustainable growth also from a position of the society' welfare, environmental protection and energy efficiency. In the research, we also confirm the statement concerning all subsystem factors transversality.

In the paper, authors expand sustainable growth idea as a synergistic result of interconnections and interdependencies between four subsystems, which determine the longterm social, environmental, energy and financial consequences. We deeper analyze how Gazprom can contribute to natural resources preservation and healthy society' environment. We identify sustainable growth traditional meaning problems and systematized contradictions. We discuss ecological economics views on financial growth. We deeper investigate a relationship among between economic growth, negentropy, and protection of the environment. Physics shows that energy is necessary for economic production and, therefore, economic growth but the mainstream theory of economic growth, pays no attention to the role of energy. Economics has attempted to address this question from a different point of view. The classic literature focused on exhaustible resources puts at the core the importance of the price mechanism and the substitution possibilities of human-made inputs for natural resources. At the same time, others stressed the economic implications of thermodynamic laws and ecology. They insisted on the limits that physical and natural processes impose on economic activity and the difficulties in invoking the financial growth mechanism because establishing property rights on environmental assets is often impossible [Pascale, 2012].

In our research, we used the CRS DEA for indicating periods when managing SGSI/ $S G R$ is better and visualized results employing information negentropy. We analyzed the transversality links between subsystems to identify moments when we can influence on the sustainable growth system. The following factors affect SGSI: production, energy savings, environmental rating, a footprint, emissions of pollutants into the atmosphere, discharge of wastewater into surface water bodies, ecological expenses, social expenses, personal expenses, financial leverage and self-financing ratio, and EBITDA. At the beginning of the study period (1996), the CRS was below 0.2, that means that sustainability, expressed by the SGSI, is relatively difficult to influence through FOOTPRINT, Emissions, Discharge. However, after 2025, a high CRS value is predicted, causing a significant increase in the degree of interaction between the input and output parameters. CRS negentropy index also confirmed this fact. SGR is up to 2020 increasing quite stable. At the same time after 2020 , the growth of this indicator we suppose with a maximum after 2025. Thus, after 2025 , the existence of the bifurcation points in terms of SGSI and SGR is predicted when presented through FOOTPRINT, Emissions, Discharge. Also, after 2025, the occurrence of the bifurcation points in terms of SGSI and SGR is predicted when exposed through a footprint, environmental expenses, social expenses, personal expenses, financial leverage, and self-financing ratio. The same way, after 2025, the occurrence of the bifurcation points in terms of SGSI and SGR is predicted when exposed through production, energy savings, and EBITDA. Research results show that emissions of pollutants into the atmosphere, as well as the discharge of wastewater into surface water bodies, decrease till 2030. SGR is further at an average level. SGSI, a footprint, environmental expenses, personal expenses, social expenses, financial leverage, and self-financing ratio, production, EBITDA and Energy Savings are at the high-level point at 2030. However, the environmental rating is quite less than nowadays. 
Nevertheless, nowadays Gazprom has deficient SGSI level. In the Russian gas industry, the main barrier to achieving high SGSI rates are shortages in environmental protection measures. It is recommended to encourage supplier' green certification and increase investments into Russian oil and gas companies' environmental projects. Besides, Tax State Regulation concerning harmful and dangerous activities concerning the environment is required.

The research hypothesis was confirmed. Sustainable growth today is closely linked to the depletion of natural resources, the level of pollution and environmental degradation, which leads to the deterioration of human health and limits the possibility of further economic development. According to the research results, Gazprom within the financial policy framework could follow nest recommendations: (a) ensuring environmental protection financing, social responsibility level, and energy efficiency actions for achieve sustainable growth; (b) consolidate financial statements in the context of sustainable growth system, focusing attention on social, energy and ecological indicators; (c) develop environmentally and social oriented complex sustainable growth system indicators; (d) initiate statelevel ecological programme aimed for defence footprint and biocapacity; (e) accented attention on energy savings and EROI for achieving company sustainability.

\section{References}

Adams C. A., Frost G. R. (2008) Integrating sustainability reporting into management practices. Accounting Forum, vol. 4, no. 32, pp. 288-302.

Bobulescu R. (2015) From Lotka's biophysics to Georgescu-Roegen's bioeconomics. Ecological Economics Journal, pp. 194-202.

Bocharnikov V.N. (2018) Spatial thinking, cultural geography and wilderness. Izvestiia Rossiiskoi Akademii Nauk. Seriia Geograficheskaia, vol.3, pp. 105-116.

Bocharnikov V.N., Huettman F. (2019) Wilderness Condition as a Status Indicator of Russian Flora and Fauna: Implications for Future Protection Initiatives. International Journal of Wilderness, vol. 25, no. 1, pp 26-39.

Bocharnikov V.N. (2012) To the geographical problem biodiversity and ecosystems savings in the Russian Far East. Problem of saving resources, vol. 1, pp. 62-66. (In Russian)

Chakrabarti C. G., Chakrabarty I. (2007) Boltzmann Entropy: Probability and Information. Entropy, vol. 52, no. 1, pp. 5-7.

Chen Y., Li C. (2011) Entropy, Substitution and Sustainable Economic Growth. Research in World Economy, vol. 2, no. 2, p. 66 .

Cleveland C., Costanza R., Hall Ch., Kaufmann K. (1984) Energy and the U.S. economy: A biophysical perspective. Science, vol. 225, no. 4665, pp. 890-897.

Daly H., Farley J. (2004) Ecological economics: principles and applications. Ecological Economics, vol.55, no. 1, pp. 538-541.

Emrouznejad A., Cabanda E. (2016) Data Envelopment Analysis and its Applications. Proceedings of the 13th International Conference on Data Envelopment Analysis (August 2015), pp. 1-203. Available at: https://emrouznejad.com/ali/publications/ (accessed: 21.02.2020).

Feng J., Feng L., Wang J., King W.C. (2018) Modeling the point of use EROI and its implications for economic growth in China. Energy, Elsevier Ltd, vol. 144, pp. 232-242.

Geniberg T. V., Ivanova N.A., Polyakova O. V. (2009) Essence and methodological base of the company's financial strategy. Novosibirsk State University Scientific Journal, no. 9, pp. 68-88. (In Russian)

Gray R. (2009) Entropy and Information Theory. Springer-Verlag, pp. 1-313.

Gupta P., Guha S., Krishnaswami S. (2013) Firm growth and its determinants. Journal of Innovation and Entrepreneurship, vol.2, no. 1, p. 15.

Gusev A. (2016) Energy Efficiency Policy in Russia. International Journal of Global Energy Issues, 16, June 2013, pp.1-8. 
Hall C.A.S., Balogh S., Murphy D.J.R. (2009) What is the Minimum EROI that a Sustainable. Energies, vol. 2, pp. 25-47.

Hall C. A.S., Lambert J. G., Balogh S. B. (2014) EROI of different fuels and the implications for society. Energy Policy Journal, vol. 64, pp. 141-152.

Hall C., Klitgaard, K. (2014) Energy and the Wealth of Nations, Springer. Available at: https://www.springer. com/gp/book/9781441993984 (accessed: 21.02.2020).

Higgins R. (1977) How much growth can a firm afford. Financial Management, vol. 6, no. 3, pp.7-16.

Husillos J., González C. L., Gil M. J.Á. (2011) The emergence of triple bottom line reporting in Spain. Spanish Journal of Finance and Accounting, vol. 40, no. 150, pp. 195-219.

Ivashkovskaya I. V. (2009) Sustainable Growth Rate: from Russian companies' evidence. St Petersburg University Journal of Economic Studies, vol. 8, no. 4, pp. 3-29. (in Russian)

Ivashkovskaya I. V. (2014) Does corporate Financial Architecture contribute to sustainable corporate growth? The evidence from Russian companies. Journal of Corporate Finance Research, vol.32, no. 4, pp.11-33.

Lambert J.G., Hall Ch., Balogh S., Gupta A., Arnold M. (2014) Energy, EROI and quality of life. Energy Policy, no. 64, pp. 153-167.

Lindenberger D., Kümmel R. (2011) Energy and the state of nations. Energy, vol. 36, no. 10, pp. 6010-6018.

Meadows D., Randers J., Meadows D. (1972) The Limits: Sinks and Sources. The Limits to Growth, Potomac Associates - Universe Books. 205 p.

Murphy D. J., Hall Ch., Dale M., Cleverland C. (2011) Order from chaos: A preliminary protocol for determining the EROI of fuels. Sustainability, vol.3, no. 10, pp. 1888-1907.

Niu (2011) The Quality Index of China's Gross Domestic Product (GDP). China Academy of Science Journal, vol. 1, no. 1, pp. 516-525. (in Chinese)

Nogovitsyn R., Sokolov A. (2014) Preliminary calculation of the EROI for the production of gas in Russia. Sustainability, vol.6, no. 10, pp.6751-6765.

Pascale A. (2012) Role of Entropy in Sustainable Economic Growth. International Journal if Academic Research in Accounting, Finance and Management Sciences, vol. 2, no. 1, pp.293-301.

Steblyanskaya A., Wang Zhen (2019). Are Sustainable Growth Indicators in Gas Market Companies Comparable? The Evidence from China and Russia. Journal of Corporate Finance Research, vol.13, no. 1, pp. 76-92.

Steblyanskaya A., Wang Zhen, Bragina Z. (2019) Financial Sustainable Growth Theory as a Result of Interaction with Energy, Social and Environmental Factors. Finance: Theory and practice, vol.98, no. 045 , pp. 134-152.

Steblyanskaya A., Wang Zhen, Denisov A., Rybachuk M. (2019) Is the implementation of energy savings and EROI increasing policy really effective in Russian gas companies? The case of JSC "Gazprom", Natural Gas Industry B. Elsevier Ltd, vol. 6, no. 6, pp. 639-651.

Tibshirani R. (1996) Regression Shrinkage and selection via the Lasso. Journal of the Royal Statistical Society. Ser. (B) (Methodological), vol. 58, no. 1, pp. 267-288.

Xie Q., Dai Q., Li Y., Jiang A. (2014) Increasing the discriminatory power of DEA using Shannon's entropy. Entropy, vol. 16, no. 3, pp.1571-1585.

Yan J., Feng L., Steblyanskaya A., Sokolov A., Iskritskaya N. (2019) Creating an energy analysis concept for oil and gas companies: The case of the Yakutiya company in Russia. Energies, vol. 12, no. 2.

Van Den Bergh J.C. (2013) Robert Ayres, ecological economics and industrial ecology. Environmental Innovation and Societal Transitions, vol.9, pp.1-7.

Received: 19.02.2019

Accepted: 11.11.2019

Authors' information:

Alina N.Steblyanskaya — PhD in Economics, Associate Professor; alina_steblyanskaya@hrbeu.edu.cn, alinamv@bk.ru

Zhen Wang - PhD in Economics, Professor; wangzhen@cup.edu.cn

Artem R.Denisov - Dr. Sci. in Economics, Associate Professor; iptema@yandex.ru

Zinaida V.Bragina - Dr. Sci. in Economics, Professor; bragzv@yandex.ru 


\section{Appendix}

Table. List of research indicators

\begin{tabular}{|c|c|c|c|}
\hline Factor & Index & Proxy & Calculation' method \\
\hline $\begin{array}{l}\text { Financial } \\
\text { Sustainability }\end{array}$ & $\begin{array}{l}\text { Higgins' Sustainable } \\
\text { Growth Rate }\end{array}$ & $S G R(H)$ & $R M \cdot A T \cdot F L \cdot R$ \\
\hline \multirow{11}{*}{$\begin{array}{l}\text { Financial } \\
\text { Factors }\end{array}$} & $\begin{array}{l}\text { Earnings before interest } \\
\text { and taxing }\end{array}$ & EBIT & Earnings before interest and taxing \\
\hline & Return on Assets & $R O A$ & (EBIT/Total Assets) $100 \%$ \\
\hline & Return on Sales & ROS & Return on sales \\
\hline & Return on Equity & $R O E$ & Net income/Equity \\
\hline & $\begin{array}{l}\text { Return On Capital } \\
\text { Employed }\end{array}$ & ROCE & EBIT/(Total Assets-Current Liabilities) \\
\hline & Return on Fixed Assets & ROFA & EBIT/Fixed Assets \\
\hline & Net working capital & NWC & Current assets-current liabilities \\
\hline & $\begin{array}{l}\text { Net working capital } \\
\text { Turnover }\end{array}$ & NWCT & Revenue/Current Assets \\
\hline & Current Ratio & $C R$ & Current assets/current liabilities \\
\hline & Revenue growth & $R G$ & $\begin{array}{l}\text { An increase of a company s sales when } \\
\text { compared to a previous quarter s revenue } \\
\text { performance }\end{array}$ \\
\hline & Net profit growth & $N P G$ & $\begin{array}{l}\text { An increase of a company s net profit when } \\
\text { compared to a previous quarter s net profit } \\
\text { performance }\end{array}$ \\
\hline & Net assets growth & $N A G$ & $\begin{array}{l}\text { An increase of a company s net assets when } \\
\text { compared to a previous quarter s net assets } \\
\text { performance. Net assets = Total assets - } \\
\text { Total Current liabilities }\end{array}$ \\
\hline & Financial leverage & $F L$ & Total Assets/Equity \\
\hline & $\begin{array}{l}\text { Operation leverage } \\
\text { degree }\end{array}$ & $D O L$ & \% change in $E B I T / \%$ change in Revenue \\
\hline & Debt equity ratio & $D E R$ & $\begin{array}{l}\text { Total liabilities/Equity. Total liabilities = } \\
\text { Equity-Assets }\end{array}$ \\
\hline & $\begin{array}{l}\text { Weighted Average Cost } \\
\text { Of Capital }\end{array}$ & WACC & $W A C C=r E \cdot k E \cdot r D \cdot k D \cdot(1-T)$ \\
\hline \multirow{2}{*}{ Energy factors } & \multirow{2}{*}{ Energy Indicators } & $L E I$ & Lambert Energy Index \\
\hline & & $E S$ & Energy Savings \\
\hline \multirow{5}{*}{$\begin{array}{l}\text { Environmental } \\
\text { factors }\end{array}$} & $\begin{array}{l}\text { Return on } \\
\text { environmental expences }\end{array}$ & ROEenv & $\begin{array}{l}\text { costs concerning environmental protection } \\
\text { and decision of pollution question/ } \\
\text { production }\end{array}$ \\
\hline & Environmental ratings & $E R$ & Gazprom' environmental ranking \\
\hline & $\begin{array}{l}\text { Production/Reserves } \\
\text { ratio }\end{array}$ & $P R P$ & Production/Reserves \\
\hline & Footprint & FP & Footprint \\
\hline & Biocapacity & $B C$ & Biocapacity (биоёмкость) \\
\hline
\end{tabular}




\begin{tabular}{|c|c|c|c|}
\hline Factor & Index & Proxy & Calculation' method \\
\hline \multirow{3}{*}{ Social factors } & $\begin{array}{l}\text { Revenue per employee } \\
\text { ratio }\end{array}$ & $R E R$ & Total Revenue / Total Number of Employees. \\
\hline & $\begin{array}{l}\text { Return on social } \\
\text { expences }\end{array}$ & ROEsr & $\begin{array}{l}\text { Costs concerning employee benefits / net } \\
\text { profit }\end{array}$ \\
\hline & Return on Labour & $R O L$ & Net Profit/ Number of employees \\
\hline
\end{tabular}

B a se d on: [Higgins, 1977; Ivashkovskaya, 2014].

\title{
Устойчивый рост компании как результат взаимодействия финансовых, энергетических, экологических и социальных факторов (на примере ПАО «Газпром»)
}

\author{
А. Н. Стеблянская ${ }^{1}$, Джен Ванг², А. Р. Денисов , 3. В. Брагина ${ }^{3,4}$ \\ ${ }^{1}$ Харбинский инженерный университет, \\ Китай, Харбин, провинция Хэйлунцзян, район Нанганг, ул. Наньтун, 145, здание 31 \\ ${ }^{2}$ Китайский университет нефти (Пекин), \\ Китай, 102249, Пекин, ул. Фусюе, 18 \\ ${ }^{3}$ Костромской государственный университет, \\ Российская Федерация, 156005, Кострома, ул. Дзержинского, 17 \\ ${ }^{4}$ МИРЭА - Российский технологический университет, \\ Российская Федерация, 119454, Москва, пр. Вернандского, 78
}

Для цитирования: Стеблянская А. Н., Джен Ванг, Денисов А. Р., Брагина 3. В. (2020) Устойчивый рост компании как результат взаимодействия финансовых, энергетических, экологических и социальных факторов (на примере ПАО «Газпром»). Вестник Санкт-Петербургского университета. Экономика. Т.36. Вып. 1. С. 134-160. https://doi.org/10.21638/spbu05.2020.107

Финансовая политика и устойчивый рост компаний часто противоречат друг другу. В статье анализируются возможности преодоления данной проблемы. Исследуется вопрос устойчивости финансового роста крупнейшей российской газовой компании ПАО «Газпром». В отличие от традиционных интерпретаций, устойчивость компании рассматривается как результат взаимодействия между финансовыми, энергетическими, экологическими и социальными подсистемами. Авторы анализируют взаимосвязь между показателями подсистемы, используя индекс устойчивого роста Хиггинса и индекс системы устойчивого роста. Результаты исследований показывают, что система устойчивого роста «Газпрома» стабильна, но во избежание дестабилизации предлагаются способы предотвращения развития барьеров на пути к устойчивому росту компании. В работе представлен подход, использующий негэнтропию Шеннона для улучшения дискриминации моделей устойчивой системы анализа охвата данных. При таком подходе эффективность анализа среды функционирования сначала рассчитывается для всех возможных подмножеств переменных и анализируется с использованием теории энтропии Шеннона для установления степени важности каждого подмножества в системе устойчивого роста «Газпрома». Затем авторы объединяют полученные значения эффективности и степени важности для получения общего показателя эффективности, который может заметно улучшить дискриминацию моделей устойчивого роста. Для визуализации трансформации устойчивости системы целесообразно использовать показатель негэнтропии. На уровень системного индекса устойчивого роста имеют влияние следующие факторы: добыча, энергосбережение, экологический рейтинг, экологический футпринт, сокращение выбросов загрязняющих веществ в атмосферу, снижение сброса сточных вод в поверхностные водные объекты, расходы, 
направленные на экологию, расходы на персонал, социальные расходы, финансовый рычаг, коэффициент самофинансирования и прибыль до вычета процентов, налога на прибыль и амортизации активов.

Ключевые слова: устойчивый рост, индекс устойчивого роста Хиггинса, методология системы устойчивого роста, социальные, энергетические и экологические факторы, влияющие на устойчивый рост, анализ среды функционирования, энтропия Шеннона.

Статья поступила в редакцию 19.02.2019

Статья рекомендована в печать 11.11 .2019

Контактная информация:

Стеблянская Алина Николаевна - канд. экон. наук, доц.; alina_steblyanskaya@hrbeu.edu.cn, alinamv@bk.ru

Джен Ванг - канд. экон. наук, проф.; wangzhen@cup.edu.cn

Денисов Артем Рубимович - д-р техн. наук, доц.; iptema@yandex.ru

Брагина Зинаида Васильевна - д-р техн. наук, проф.; bragzv@yandex.ru 